\title{
The Effect of Nanofluid Volume Concentration on Heat Transfer and Friction Factor inside a Horizontal Tube
}

\author{
Adnan M. Hussein, ${ }^{1,2}$ K. V. Sharma, ${ }^{1}$ R. A. Bakar, ${ }^{1}$ and K. Kadirgama1 \\ ${ }^{1}$ Faculty of Mechanical Engineering, University Malaysia Pahang, 26600 Pekan, Pahang, Malaysia \\ ${ }^{2}$ Al-Haweeja Institute, Foundation of Technical Education, Iraq \\ Correspondence should be addressed to Adnan M. Hussein; adnanphd2012@gmail.com
}

Received 11 April 2013; Accepted 18 June 2013

Academic Editor: Yun Suk Huh

Copyright (c) 2013 Adnan M. Hussein et al. This is an open access article distributed under the Creative Commons Attribution License, which permits unrestricted use, distribution, and reproduction in any medium, provided the original work is properly cited.

\begin{abstract}
The additives of solid nanoparticles to liquids are significant enhancement of heat transfer and hydrodynamic flow. In this study, the thermal properties of three types of nanoparticles $\left(\mathrm{Al}_{2} \mathrm{O}_{3}, \mathrm{TiO}_{2}\right.$, and $\left.\mathrm{SiO}_{2}\right)$ dispersed in water as a base fluid were measured experimentally. Forced convection heat transfer turbulent flow inside heated flat tube was numerically simulated. The heat flux around flat tube is $5000 \mathrm{~W} / \mathrm{m}^{2}$ and Reynolds number is in the range of $5 \times 10^{3}$ to $50 \times 10^{3}$. CFD model by finite volume method used commercial software to find hydrodynamic and heat transfer coefficient. Simulation study concluded that the thermal properties measured and Reynolds number as input and friction factor and Nusselt number as output parameters. Data measured showed that thermal conductivity and viscosity increase with increasing the volume concentration of nanofluids with maximum deviation $19 \%$ and $6 \%$, respectively. Simulation results concluded that the friction factor and Nusselt number increase with increasing the volume concentration. On the other hand, the flat tube enhances heat transfer and decreases pressure drop by $6 \%$ and $-4 \%$, respectively, as compared with circular tube. Comparison of numerical analysis with experimental data available showed good agreement with deviation not more than $2 \%$.
\end{abstract}

\section{Introduction}

The increasing demand for more efficient heat transfer fluids in many applications led to enhance heat transfer to meet the cooling challenge necessary such as the electronics, photonics, transportation, and energy supply industries [1]. The thermal conductivity of metallic liquids is much greater than that of nonmetallic liquids. Therefore, the thermal conductivities of fluids that contain suspended solid metallic particles could be expected to be significantly higher than those of conventional heat transfer fluids as shown in Table 1. Sen Gupta et al. [2] carried out experimental study to measure thermal conductivity in graphene nanofluids using the transient hotwire method. They also studied carbon nanotube (CNT) and graphene oxide nanofluids. The magnitude of enhancement was between $\mathrm{CNT}$ and metallic/metal oxide nanofluids. Multicurrent hot-wire technique was used by Peñas et al. [3], to measure thermal conductivity of $\mathrm{SiO}_{2}$ and $\mathrm{CuO}$ in water and ethylene glycol nanofluids with concentrations up to $5 \%$ in mass fraction. They found a good agreement within $2 \%$, with published thermal conductivities of the pure fluids. Optimizing thermal conductivity of nanofluids proposed by [4], there were various nanoparticles involving $\mathrm{Al}_{2} \mathrm{O}_{3}$ with different sizes, $\mathrm{SiC}$ with different shapes, $\mathrm{MgO}, \mathrm{ZnO}, \mathrm{SiO}_{2}, \mathrm{Fe}_{3} \mathrm{O}_{4}$, $\mathrm{TiO}_{2}$, diamond, and carbon nanotubes. The base fluids used deionized water, ethylene glycol (EG), glycerol, silicone oil, and the binary mixture of DW and EG. Results showed that the thermal conductivity enhancements of nanofluids could be influenced by multifaceted factors including the volume fraction of nanoparticles, the tested temperature, thermal conductivity of the base fluid, nanoparticles size, pretreatment process, and the additives of the fluids. The viscosity and specific heat of silicon dioxide $\left(\mathrm{SiO}_{2}\right)$ nanoparticles with various diameters $(20,50$, and $100 \mathrm{~nm})$ in a $60: 40$ (by weight) ethylene glycol and water mixture were investigated experimentally by Namburu et al. [5]. Results showed new correlation from experimental data, which related viscosity with particle volume percent and nanofluid temperature. Also, specific heat of $\mathrm{SiO}_{2}$ nanofluid for various particle volume concentrations was presented. Bahiraei et al. [6] examined the 
TABLE 1: Thermal conductivity enhancement.

\begin{tabular}{|c|c|c|c|}
\hline Year & Nanofluid & Used studies conducted & Reference \\
\hline 1993 & $4.3 \%\left(\mathrm{Al}_{2} \mathrm{O}_{3}, \mathrm{SiO}_{2}\right.$, and $\left.\mathrm{TiO}_{2}\right)$ dispersed in water & $\begin{array}{l}26 \%, 7 \% \text {, and } 11 \% \text { enhancement in thermal } \\
\text { conductivity }\end{array}$ & Masuda et al. [37] \\
\hline 1999 & $4 \% \mathrm{CuO}, \mathrm{Al}_{2} \mathrm{O}_{3}$ dispersed in water & $20 \%$ enhancement in thermal conductivity & Lee et al. [38] \\
\hline 2000 & $2.5-7.5 \%$ (Cu nanoparticles)-water & $\begin{array}{l}\text { Thermal conductivity ratio varies from } 1.24 \\
\text { to } 1.78 \%\end{array}$ & Xuan and Li [39] \\
\hline 2001 & $\mathrm{Cu}$ nanoparticles dispersed in ethylene glycol & $\begin{array}{l}\text { Effective thermal conductivity of ethylene } \\
\text { glycol improved by up to } 40 \% \text { through the } \\
\text { dispersion on } 0.3 \% \mathrm{Cu} \text { nanoparticles }\end{array}$ & Eastman et al. [40] \\
\hline 2007 & $\begin{array}{l}\mathrm{CuO} \text { and } \mathrm{Al}_{2} \mathrm{O}_{3} \text { nanoparticles dispersed in water } \\
\text { (effect of temperature) }\end{array}$ & $\begin{array}{l}4 \mathrm{vol} \% . \mathrm{Al}_{2} \mathrm{O}_{3} \text { dispersed water nanofluids } \\
\text { thermal conductivity raise } 9.4 \% \text { to } 24.3 \% \text { at } \\
\text { increase in temperature from } 21 \text { to } 51^{\circ} \mathrm{C}\end{array}$ & Das et al. [1] \\
\hline 2006 & $5 \%$ dispersing $\mathrm{TiO}_{2}$ sphere, rod & $\begin{array}{l}30-33 \% \text { enhancement in thermal } \\
\text { conductivity }\end{array}$ & Murshed et al. [41] \\
\hline 2006 & $\begin{array}{l}\text { 1\% CuO-ethylene glycol } \\
\text { Dispersing } 1 \text { vol.\% } \mathrm{SiO}_{2} \text {-water } \\
\text { Dispersing } 1 \text { vol.\% carbon nanotube }\end{array}$ & $\begin{array}{l}5 \% \text { enhancement } \\
3 \% \text { enhancement in water based nanofluid } \\
7 \% \text { enhancement in water based nanofluid }\end{array}$ & Hwang et al. [42] \\
\hline 2007 & $(0.1-2 \%)$ Graphite $106 \mathrm{~nm}+$ water & 10-37\% thermal conductivity enhancement & Zhu et al. [43] \\
\hline 2008 & Water + EG (1\% volume concentration) & $31 \%$ thermal conductivity enhancement & Karthikeyan et al. [44] \\
\hline 2009 & $\begin{array}{l}4 \% \mathrm{Al}_{2} \mathrm{O}_{3}(15-50 \mathrm{~nm})+\text { water } \\
4 \% \mathrm{Cu}(25-60 \mathrm{~nm})+\text { water }\end{array}$ & $\begin{array}{l}13 \% \text { enhance thermal conductivity } \\
15 \% \text { enhance thermal conductivity }\end{array}$ & Wang and Li. [45] \\
\hline 2010 & $0.5 \% \mathrm{Al}_{2} \mathrm{O}_{3}$-water & Enhancement thermal conductivity $31 \%$ & Sundar and Sharma. [8] \\
\hline 2013 & $\begin{array}{l}0.1 \% \text { alumina dispersed in ethylene glycol and } \\
\text { propylene glycol }\end{array}$ & $\begin{array}{l}\text { Thermal conductivity enhancement ratios } \\
\text { are } 38.71 \% \text { and } 40.2 \% \text {, respectively, for } \\
\text { ethylene glycol and propylene glycol }\end{array}$ & Dehkordi et al. [46] \\
\hline 2012 & $\begin{array}{l}\mathrm{Cu} \text { dispersed with aqueous solution of cetyltrimethyl } \\
\text { ammonium chloride/sodium salicylate }\end{array}$ & $\begin{array}{l}\text { Thermal conductivity increases with } \\
\text { increasing temperature and increasing } \\
\text { particle volume fraction }\end{array}$ & Priya et al. [47] \\
\hline 2013 & $\mathrm{Al}_{2} \mathrm{O}_{3}$-water & $\begin{array}{l}\text { Thermal conductivity and specific heat } \\
\text { enhancement }\end{array}$ & Barbés et al. [48] \\
\hline
\end{tabular}

effect of temperature and volume fraction on the viscosity for $\mathrm{TiO}_{2}$-water nanofluid. Results were recorded and analyzed within a temperature range of 25 to $70^{\circ} \mathrm{C}$ and volume fraction $0.1,0.4,0.7$, and $1 \%$. Viscosity was measured experimentally by [7] using a rheometer. It was obtained as a function of the nanoparticles mass fraction and shear rate. Water was already used as a base fluid and two different materials single wall carbon nanohorn (SWCNH) and titanium dioxide $\left(\mathrm{TiO}_{2}\right)$. Results proposed empirical correlation equations of viscosity.

Wide variety of practical and industrial applications of forced convection in a flat tube as heat exchangers, heating processes, power generation, chemical processes, microelectronics, and cooling processes led to interest in this type of studies [8-16]. Duangthongsuk and Wongwises [17] found the heat transfer coefficient and friction factor of the nanofluid $\mathrm{TiO}_{2}$-water flowing in a horizontal double-tube counterflow heat exchanger under turbulent flow conditions experimentally and showed that the heat transfer coefficient of nanofluid is higher than that of the base liquid. Forced convection turbulent flow of $\mathrm{Al}_{2} \mathrm{O}_{3}$-water nanofluid inside an annular tube with variable wall temperature was investigated experimentally by Prajapati [18]; the results showed the enhancement of heat transfer due to the nanoparticle presence in the fluid. The forced convection flow between two corrugated cylinders was studied by Kittur [19]; results found friction factor and heat transfer on the boundaries. Horizontal double-tube heat exchanger counter turbulent flow was studied numerically by Bozorgan et al. [20]; $\mathrm{Al}_{2} \mathrm{O}_{3}$ water nanofluid of $7 \mathrm{~nm}$ with volume concentrations up to $2 \%$ was selected as a coolant use; the results showed that the pressure drop of nanofluid is slightly higher than water and increases with the increase in volume concentrations. Forced convection of nanofluid of a double-tube counterflow heat exchanger using CFD simulation FLUENT software was investigated by Demir et al. [21]. A double-tube coaxial heat exchanger heated by solar energy using Aluminum oxide nanofluid was presented experimentally and numerically by Luciu et al. [22]; results showed that nanofluids have a higher performance of heat transfer than base fluid.

In this study thermal conductivity and viscosity of three types of nanofluids $\left(\mathrm{Al}_{2} \mathrm{O}_{3}, \mathrm{SiO}_{2}\right.$, and $\left.\mathrm{TiO}_{2}\right)$ in water are measured experimentally. Simulation study by using commercial software to solve governing equation of forced convection heat transfer through flat tube was conducted. The data measured was used as inputs parameters, and friction factor and heat transfer coefficient represented output parameters. Results were compared with experimental data available in the literature. 


\section{Thermal Properties Measurements}

2.1. Density and Specific Heat. Many of researchers used regression equations of density $\left(\rho_{\mathrm{nf}}\right)$ and specific heat $\left(C_{\mathrm{nf}}\right)$ [23] as

$$
\begin{gathered}
\rho_{\mathrm{nf}}=\left(\frac{\phi}{100}\right) \rho_{p}+\left(1-\frac{\phi}{100}\right) \rho_{\mathrm{f}}, \\
C_{\mathrm{nf}}=\frac{(\phi / 100)(\rho C)_{p}+(1-(\phi / 100))(\rho C)_{\mathrm{f}}}{\rho_{\mathrm{nf}}} .
\end{gathered}
$$

2.2. Thermal Conductivity. Nanofluids were prepared in thermodynamics laboratory of Mechanical Engineering Faculty University Malaysia Pahang. Nanopowders were purchased from US Research Nanomaterials, Inc. (NovaScientific Resources (M) Sdn. Bhd.). They represented three types of commercial nanoparticles $\left(\mathrm{Al}_{2} \mathrm{O}_{3}, \mathrm{TiO}_{2}\right.$, and $\left.\mathrm{SiO}_{2}\right)$ as shown in Figure 1 dispersed in water as a base fluid. Water was prepared in a laboratory by double distillation before using it for the experiments. The nanoparticles have size diameters of 13,30 , and $30 \mathrm{~nm}$, respectively. Measured quantities of nanoparticles were dispersed in distilled water to obtain mass concentration $\phi$ nanofluids. The aid of mechanical stirrers was used to achieve a homogenously dispersed solution. This method depended on [24-27] and was then subjected to ultrasonics for at least $3 \mathrm{hrs}$ to break up any residual agglomerations. Mass of nanoparticles $\left(m_{p}\right)$ and water $\left(m_{\mathrm{f}}\right)$ was measured with the accuracy of $0.001 \mathrm{~g}$ to estimate weight percentage $(\phi)$ using [25]

$$
\phi=\left(\frac{m_{p}}{\left(m_{p}+m_{\mathrm{f}}\right)}\right) \times 100 .
$$

Equation (3) was used to estimate the volume concentration of nanofluid $\phi$ depending on nanoparticles density $\left(\rho_{p}\right)$ and base fluid density $\left(\rho_{\mathrm{f}}\right)$ at $25^{\circ} \mathrm{C}$ :

$$
\Phi=\frac{m_{p} / \rho_{p}}{\left(m_{p} / \rho_{p}\right)+\left(m_{\mathrm{f}} / \rho_{\mathrm{f}}\right)} .
$$

Sedimentation of nanoparticles at the bottom of the samples led to change of physical properties of the bulk nanofluids with time $[26,27]$. The measurement of the thermal properties of the nanofluids requires many individual measurements for at least one month, so should take to check sample stability. Samples were checked after finishing each test but no visible sedimentation was found.

The transient hot-wires method as shown in Figure 1 was used to measure thermal conductivity of nanofluids experimentally. The wire placed along the axis of the container which was surrounded by the fluid whose thermal conductivity is to be measured. Platinum has high electrical resistivity that is, $1.06 \times 10^{-7} \Omega \mathrm{m}$ (at $20^{\circ} \mathrm{C}$ ) and order of magnitude higher than that of other metals. Also, it has a temperature coefficient of resistance of $0.0003925^{\circ} \mathrm{C}^{-1}$ (for pure platinum), which is much higher than that of other metals chosen as material of wire. The wire is to be used as a line heat source, so the wire diameter was kept within $100 \mu \mathrm{m}$. The length of the wire was kept to just a few centimeters, which compared to the wire diameter represents an infinitely long line heat source, assuring one directional (radial) heat transfer. Calibration method was used with standard fluid (glycerin) which brought with devices already; the error among reading data and the standard are 0.0023 . After that verification was performed by using the pure liquid (water) and comparing with standard and the error among them is 0.0014 . Thermal conductivity values were estimated by [28-30]

$$
\frac{k_{\mathrm{nf}}}{k_{\mathrm{f}}}=\frac{k_{p}+(n-1) k_{\mathrm{f}}-(n-1) \phi\left(k_{\mathrm{f}}-k_{p}\right)}{k_{p}+(n-1) k_{\mathrm{f}}+\phi\left(k_{\mathrm{f}}-k_{p}\right)},
$$

where $n$ represents the shape factor which was equal to 3 for spherical nanoparticles. The standard deviation corresponding to the series of individual data measured for each nanofluid was in all cases less than $0.15 \%$.

2.3. Viscosity. To evaluate the thermal properties of nanofluids the viscosity is a significant indication. A commercial Brookfield DV-I prime viscometer was used to measure viscosity at different temperatures and rotor RPMs was shown in Figure 1. Base fluid (water) was used to measure viscosity for calibration; after that nanofluids were used to measure viscosity. Viscosity of nanofluid $\left(\mu_{\mathrm{nf}}\right)$ was determined from the well-known Einstein equation for estimating viscosity, which is validated to spherical particles and volume concentration less than 5.0 vol. \% and defined as [31-33]

$$
\mu_{\mathrm{nf}}=(1+2.5 \phi) \mu_{\mathrm{f}}
$$

\section{Computational Method}

3.1. Physical Model. Cylindrical geometry coordinates of problem undertaken in Figure 2 are shown. Dimensions of the flat tube are major and minor diameter $(D=9 \mathrm{~mm}$, $d=3 \mathrm{~mm}$ ); the length $(L)$ and hydraulic diameter $\left(D_{h}\right)$ of the flat tube are $500 \mathrm{~mm}$ and $4.68 \mathrm{~mm}$. Reynolds number was calculated regarding hydraulic diameter $\left(D_{h}\right)$ as [34]

$$
\begin{gathered}
D_{h}=\frac{4 \times\left[(\pi / 4) d^{2}+(D-d) \times d\right]}{\pi \times d+2 \times(D-d)}, \\
\operatorname{Re}=\frac{\rho_{\mathrm{nf}} \times D_{h} \times u}{\mu_{\mathrm{nf}}} .
\end{gathered}
$$

The problem undertaken was assumed to be twodimensional, steady, incompressible and Newtonian turbulent fluid flow, constant thermophysical properties of nanofluid, no effect of gravity and heat conduction in the axial direction and wall thickness of tubes neglected.

3.2. Governing Equations. Infinitesimal (less than $100 \mathrm{~nm}$ ) solid particles were assumed to be able to use single phase approach, so single phase approach was adopted for nanofluid modeling. For all these assumptions, the dimensional conservation equations for steady state mean conditions are as 

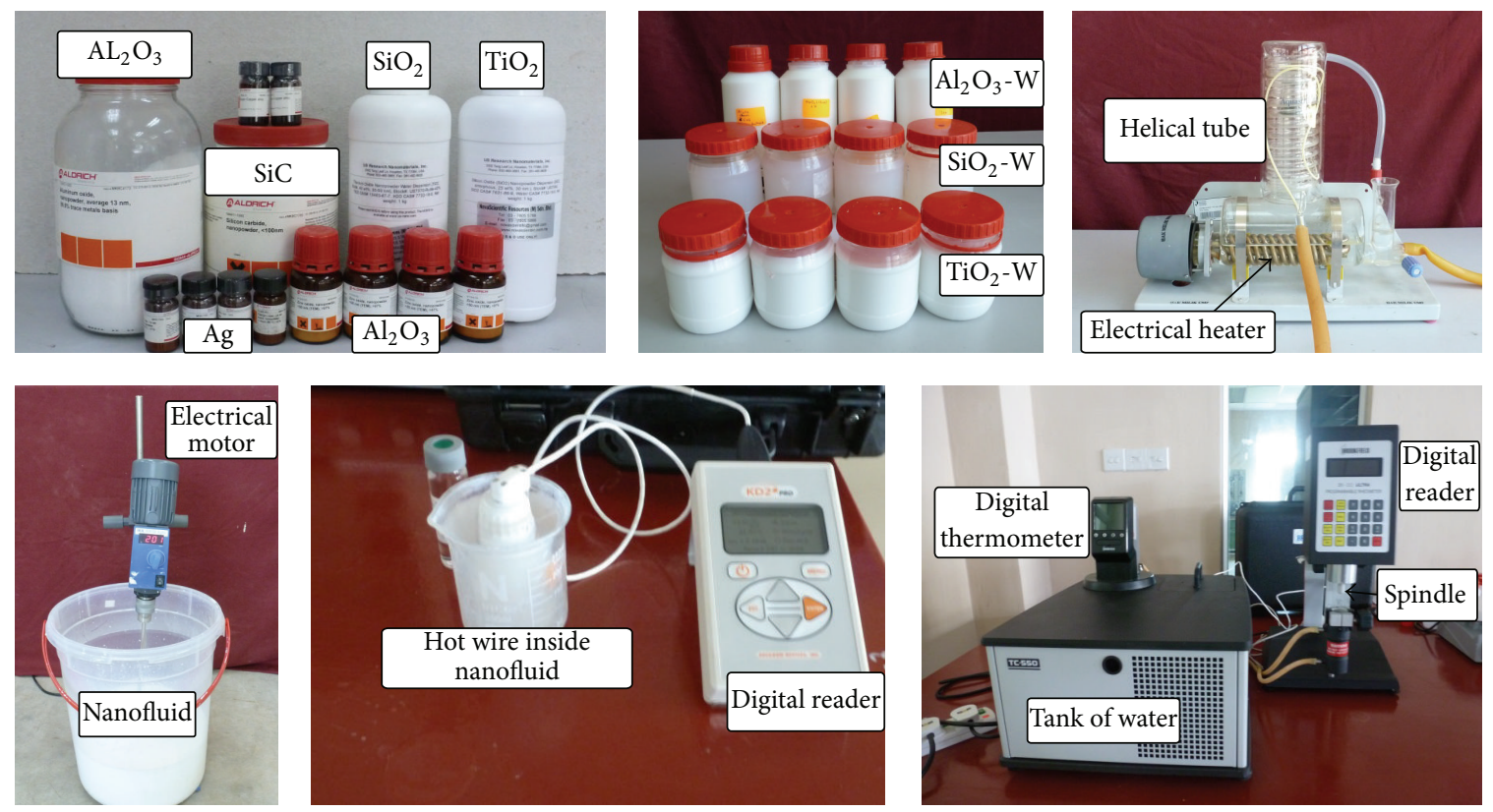

FIGURE 1: Materials and devices used in experimental work.

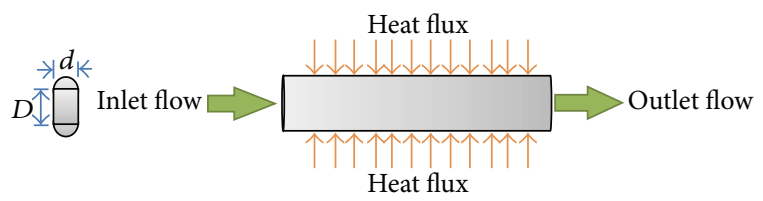

FIGURE 2: Schematic of problem undertaken.

follows: continuity, momentum, and energy equations Bejan [35]

$$
\begin{gathered}
\frac{\partial u}{\partial x}+\frac{1}{r} \frac{\partial}{\partial r}\left(r \rho_{\mathrm{nf}} u\right)=0 \\
u \frac{\partial u}{\partial x}+v \frac{\partial}{\partial r}\left(\rho_{\mathrm{nf}} u\right)=-\frac{\partial P}{\partial x}+\frac{1}{r} \frac{\partial}{\partial r}\left[r\left(v+\varepsilon_{H}\right) \frac{\partial u}{\partial r}\right], \\
\frac{1}{r} \frac{\partial}{\partial r}(\rho u T)=\frac{1}{r} \frac{\partial}{\partial r}\left[r\left(\alpha+\varepsilon_{H}\right) \frac{\partial T}{\partial r}\right]+\frac{1}{r^{2}} \frac{\partial}{\partial x}\left\{\frac{k_{\mathrm{nf}}}{C_{p}} \frac{\partial T}{\partial x}\right\} .
\end{gathered}
$$

High Reynolds number as input parameter was estimated; pressure treatment adopted SIMPLE scheme and turbulent viscous $k-\varepsilon$ model was employed; converged solutions were considered for residuals lower than $10^{-6}$ for all the governing equations. The results of simulation for nanofluid were compared with the equations of Blasius (8) for friction factor and Dittos-Boelter equation (9) for $\mathrm{Nu}$ as [36]:

$$
\begin{gathered}
\mathrm{f}=\frac{0.316}{\mathrm{Re}^{0.25}}, \\
\mathrm{Nu}=\frac{h_{\mathrm{f}}}{k_{\mathrm{f}}} D_{\text {eff }}=0.023 \operatorname{Re}^{0.8} \operatorname{Pr}^{0.4} .
\end{gathered}
$$

3.3. Boundary Conditions. Volume concentration nanofluids $(1,1.5,2$, and $2.5 \%)$ at $25^{\circ} \mathrm{C}$ base temperature were used for nanofluid as input. For comparison purposes, water was employed as the working fluid. CFD studies were carried out with uniform velocity profile at the inlet and pressure outlet condition used at the outlet of the flat tube. Turbulent intensity ( $I$ ) was specified for an initial guess of turbulent quantities $(k$ and $\varepsilon$ ). The turbulent intensity calculated for each case based on the formula

$$
I=0.16 \times \mathrm{Re}^{-1 / 8} .
$$

The walls of tube were assumed to be perfectly smooth and the constant heat flux condition were specified on the inside tube wall with a value of $5000 \mathrm{~W} / \mathrm{m}^{2}$. Reynolds number varied from $1 \times 10^{4}$ to $1 \times 10^{5}$ at each step of iterations as input data. The friction factor and $\mathrm{Nu}$ were introduced as output data.

3.4. Grid Independence Test. Grids independence in GAMBIT software for flat tube as $1000 \times 50$ cells and $1000 \times 50$, subdivisions in the axial length, and surface face, respectively, were tested. To find the most suitable size of mesh faces, grid independent test was performed for the physical model. In this study, rectangular cells were used to mesh the surfaces of the tube wall but triangular cells were used to mesh the surfaces of gap as shown in Figure 3. The grid independence was checked by using different grid systems and four mesh faces were considered $(1000 \times 20,800 \times 50$ and $800 \times 20)$ for pure water. Nusselt number was estimated for all four mesh faces and results were proper. However, any number of mesh faces for these four cases can be used, but in this study, mesh faces with $1000 \times 50$ were adopted as the best in terms of accuracy as shown in Figure 4. 


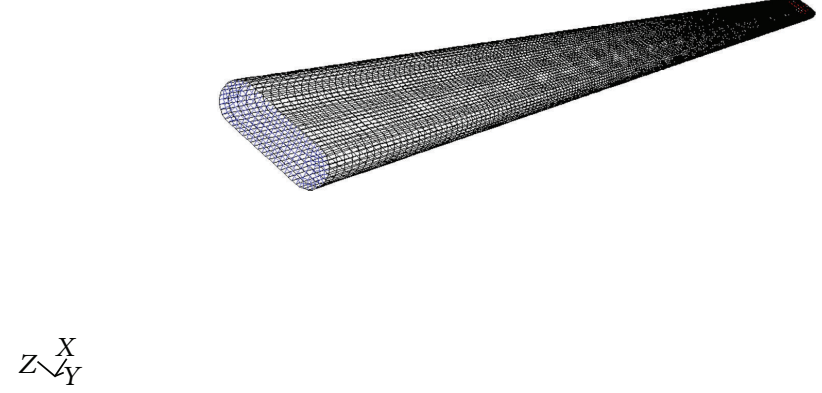

FIgUre 3: Mesh generated by GAMBIT.

3.5. CFD Simulation. CFD simulations used FLUENT software with solver strategy. Gambit software was used to analyze problems. To make possible numerical solution of governing equations, single phase conservation equations were solved by control volume approach then by converting them to a set of algebraic equations. Simulation results were tested by comparing the predicted results $[8,17,49]$ that used circular heated tube in experimental work. FLUENT software was used in CFD analysis in the literature and a detailed description of the mathematical model can be found in the FLUENT User's Guide [50]. CFD modeling region could be classified into few major steps: preprocess stage, the geometry of problem undertaken is constructed as flat narrow and computational mesh generated in GAMBIT. It followed by the physical model that boundary conditions and other parameters were appropriately defined in models setup and solving stage. All scalar values and velocity components of the problem were calculated at the center of control volume interfaces where the grid schemes were used intensively. Throughout the iterative process accurate monitoring of the residuals was done. When the residuals for all governing equations were lower than $10^{-6}$, all solutions were assumed to be converged. Finally, the results could be obtained when FLUENT iterations lead to converged results defined by a set of converged criteria. The friction factor and Nusselt number inside elliptical tube could be obtained throughout the computational domain in the postprocess stage.

\section{Results and Discussion}

The thermal conductivity always increased when nanopowders addition on base fluid to prepare nanofluid. Thermal conductivity of $\left(\mathrm{Al}_{2} \mathrm{O}_{3}, \mathrm{TiO}_{2}\right.$, and $\left.\mathrm{SiO}_{2}\right)$ nanofluids at $25^{\circ} \mathrm{C}$ were measured from $1 \%$ to $2.5 \%$ volume concentration. Figure 5 indicated thermal conductivity of nanofluid with volume concentration at temperature $25^{\circ} \mathrm{C} . \mathrm{Al}_{2} \mathrm{O}_{3}$ nanofluid has the highest values of thermal conductivity followed by $\mathrm{TiO}_{2}$ and $\mathrm{SiO}_{2}$ suspended in water. The nanoparticles have significant thermal conductivity enhancement in water [51]. The theoretical data of thermal conductivity as (4) was indicated for pure water as solid black line to compare with data measured. The experimental data of other researchers of was indicated to validate data measured, and there is good agreement with deviation no more than $2 \%$ that may be related

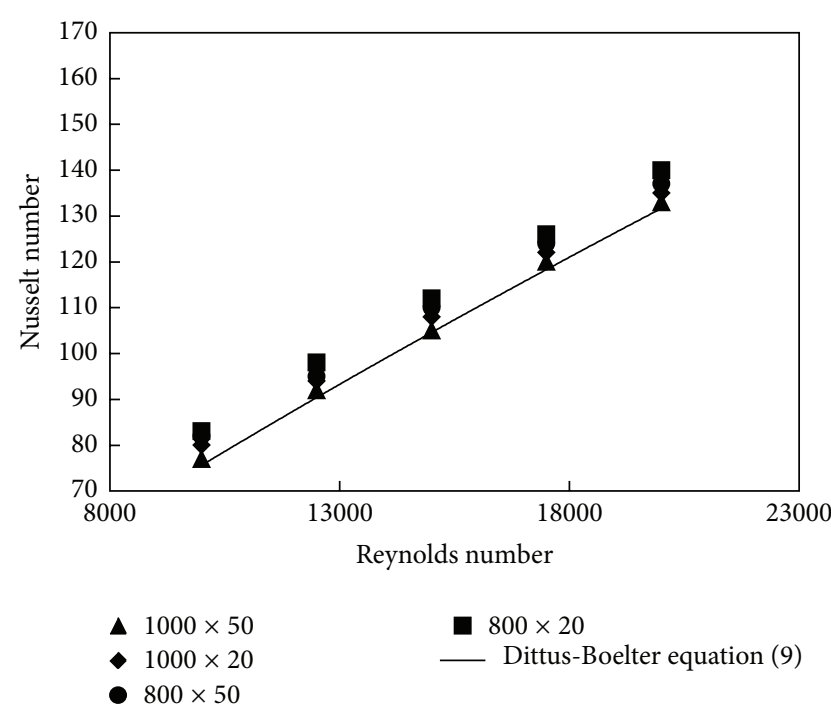

FIgURE 4: Optimum mesh grid size of Nusselt number with Reynolds number at $25^{\circ} \mathrm{C}$.

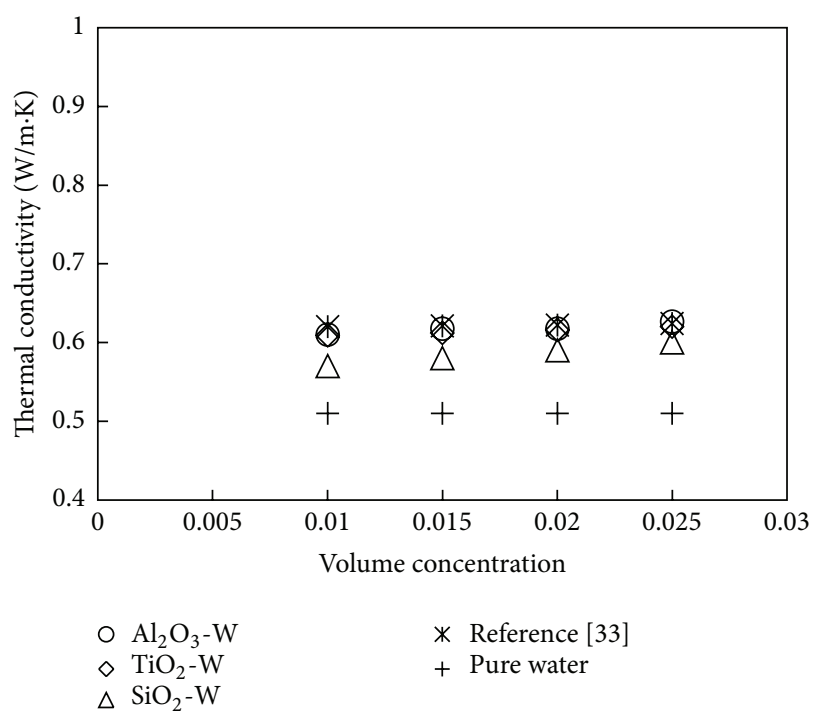

FIGURE 5: Thermal conductivity of nanofluid and base fluid at different volume concentration.

to different nanoparticle size [51]. The enhancement ( $\eta \%)$ of thermal conductivity represented percentage deviation of thermal conductivity of nanofluids against base fluid $\eta \%=$ $\left(\left(k_{\mathrm{nf}}-k_{w}\right) / k_{\mathrm{nf}}\right) \times 100$ and not more than $20 \%$ as compared with base fluid. Experimental data of viscosity of nanofluids and base fluid was measured from $1 \%$ to $2.5 \%$ volume concentration at $25^{\circ} \mathrm{C}$. The expected values of the shear rate range from 200 to $1300 \mathrm{~s}$ and all measured data is close to this range and the percentage average deviation is about $4 \%$. The experimental data of viscosity was presented in Figure 6 with volume concentrations, theoretical data of viscosity as (5) showed for pure water as solid black line and the experimental 


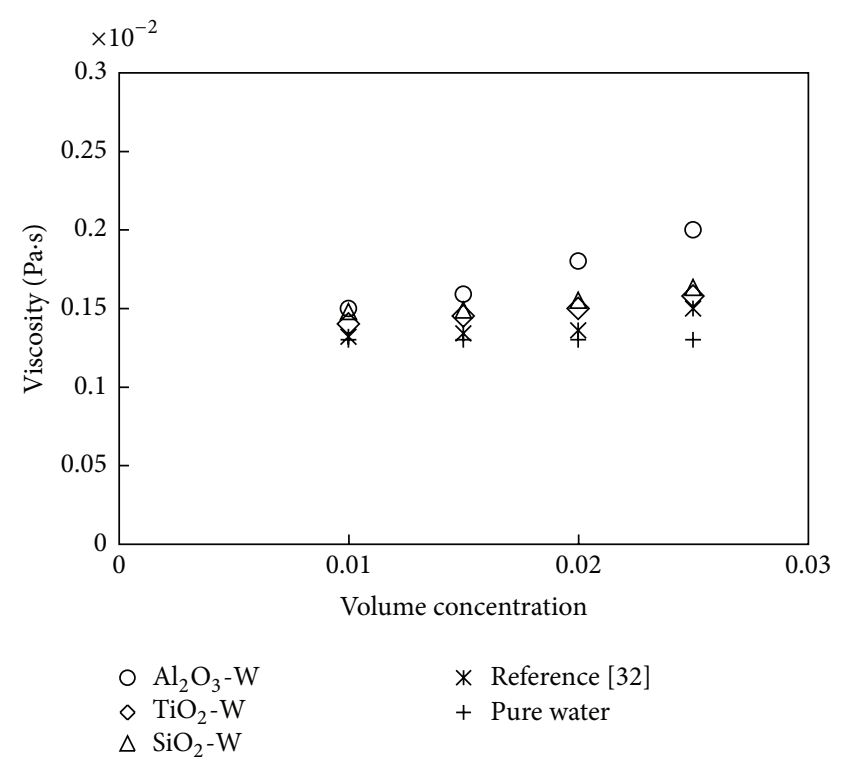

FIGURE 6: Viscosity of nanofluid and base fluid at different volume concentration.

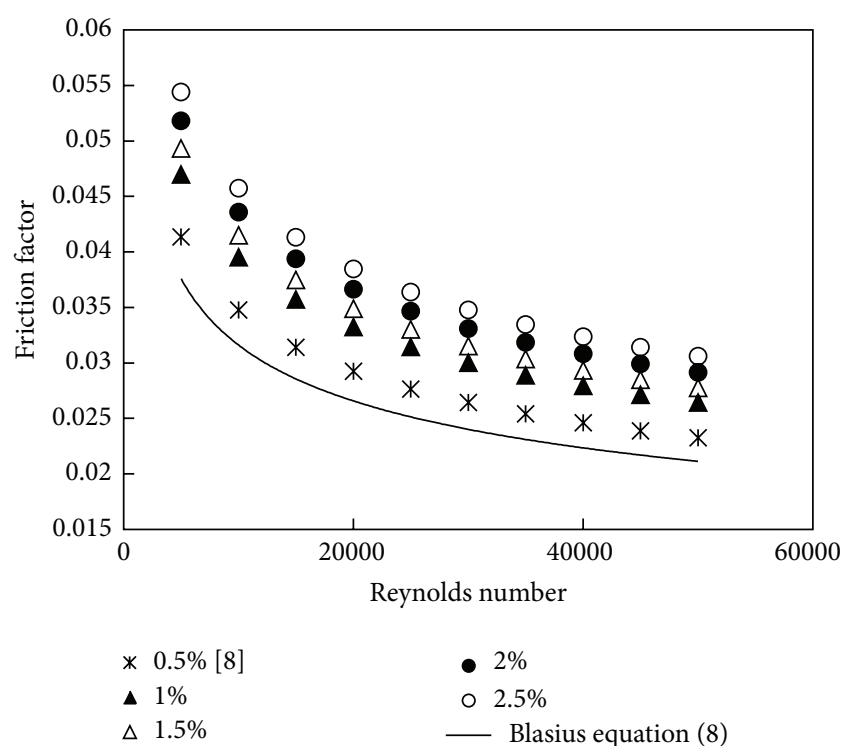

Figure 7: The effect of volume concentration of $\mathrm{Al}_{2} \mathrm{O}_{3}$-water on friction factor at different Reynolds number.

data of other investigators to validate data measured. The viscosity decreased $(\lambda \%)$ represented percentage deviations among experimental data of nanofluids and base fluid in the the range 1.2 to $6 \%$. The increase in viscosity with the increase of volume concentration was due to increase in percentage deviation which might be related to not using any surfactant or chemical additives when preparing nanofluids [52]. It seems $\mathrm{Al}_{2} \mathrm{O}_{3}$ that nanofluid has the highest values of viscosity followed by $\mathrm{SiO}_{2}$ and $\mathrm{TiO}_{2}$; finally pure water has the lowest viscosity. Nanofluids showed an increase in viscosity with the increase in volume concentration, similar behavior of base fluid. As compared to other investigators for both the thermal

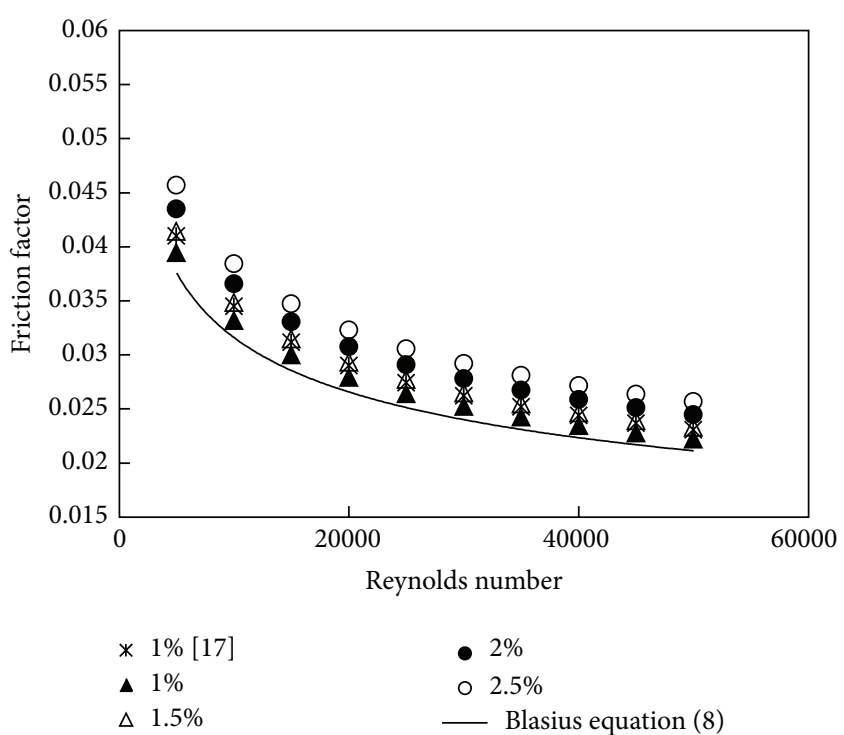

FIGURE 8: The effect of volume concentration of $\mathrm{TiO}_{2}$-Water on friction factor at different Reynolds number.

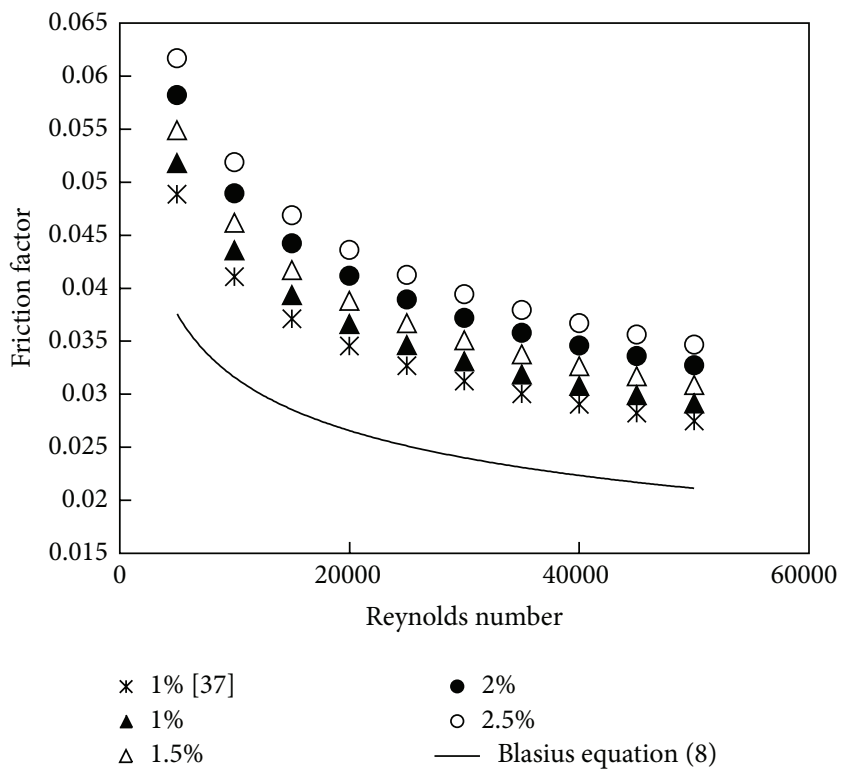

FIGURE 9: The effect of volume concentration of $\mathrm{SiO}_{2}$-Water on friction factor at different Reynolds number.

conductivity and viscosity data, the results indicated that there was difference among measured data and correlations; the reason may be due to various parameters such as particle preparation (different condition and accuracy) [53], particle size (the various size due to different thermal properties), the measurement technique, or even different particle sources $[31,32]$. The effect of different volume concentration on friction factor is shown in Figures 7, 8, and 9 at the range of 1$2.5 \%$ nanoparticle volume concentration. The results revealed that the nanofluid with highest concentration of volume $2.5 \%$ has the highest friction factor at all Reynolds numbers. The reason of increasing of friction factor with the increasing 


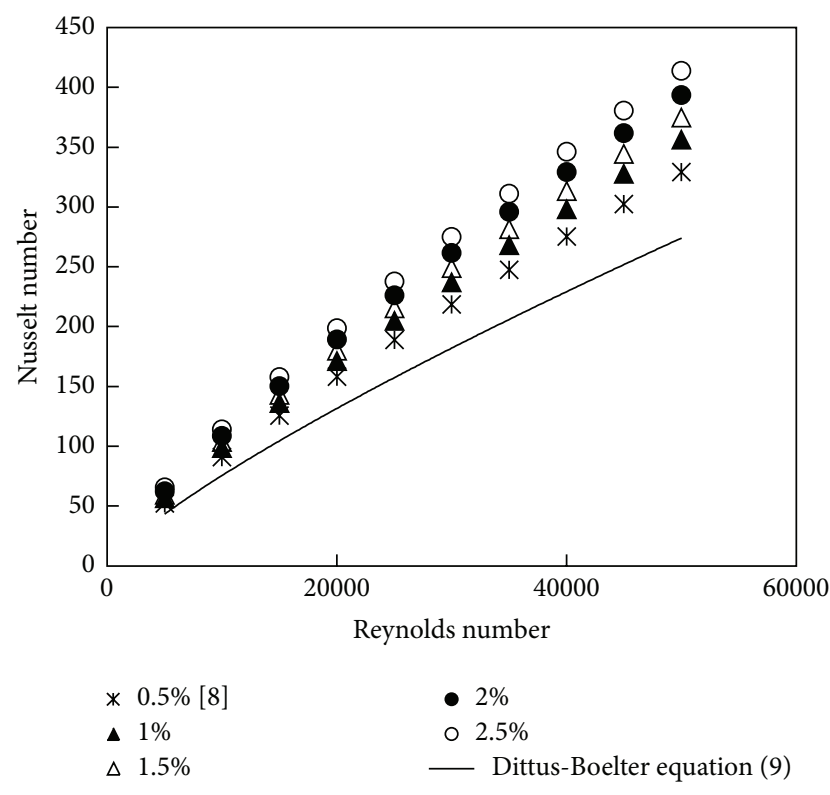

FIgURE 10: The effect of volume concentration of $\mathrm{Al}_{2} \mathrm{O}_{3}$-Water on Nusselt number at different Reynolds number.

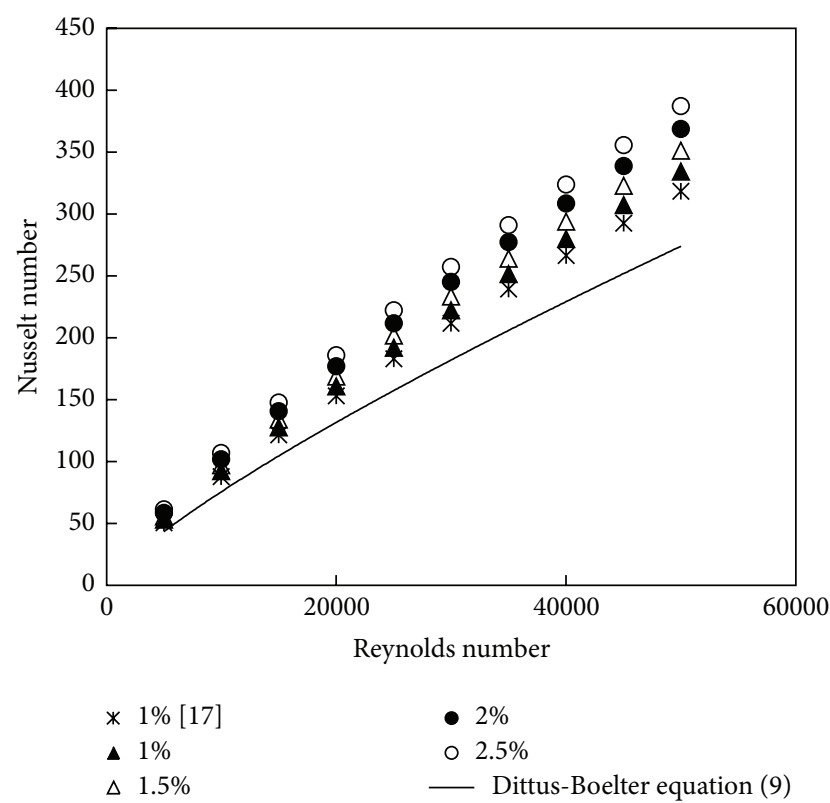

FIgure 11: The effect of volume concentration of $\mathrm{TiO}_{2}$-Water on Nusselt number at different Reynolds number.

of concentration of volume of nanofluid is the increasing of fluid viscosity which reduced the moving of fluid. The friction factor values of $\mathrm{SiO}_{2}$-water nanofluid appear higher than those of other types of nanofluid followed by $\mathrm{Al}_{2} \mathrm{O}_{3}$ and $\mathrm{TiO}_{2}$ in water. On the other side, the CFD analysis of pure water inside flat tube was compared with Blasius equation (8) for water inside circular tube which was indicated as black solid line. It appears that the values of friction factor at flat tube are less than that at circular tube, and this was achieved to use flat tube to decrease pressure drop. Figures 10, 11, and 12 show

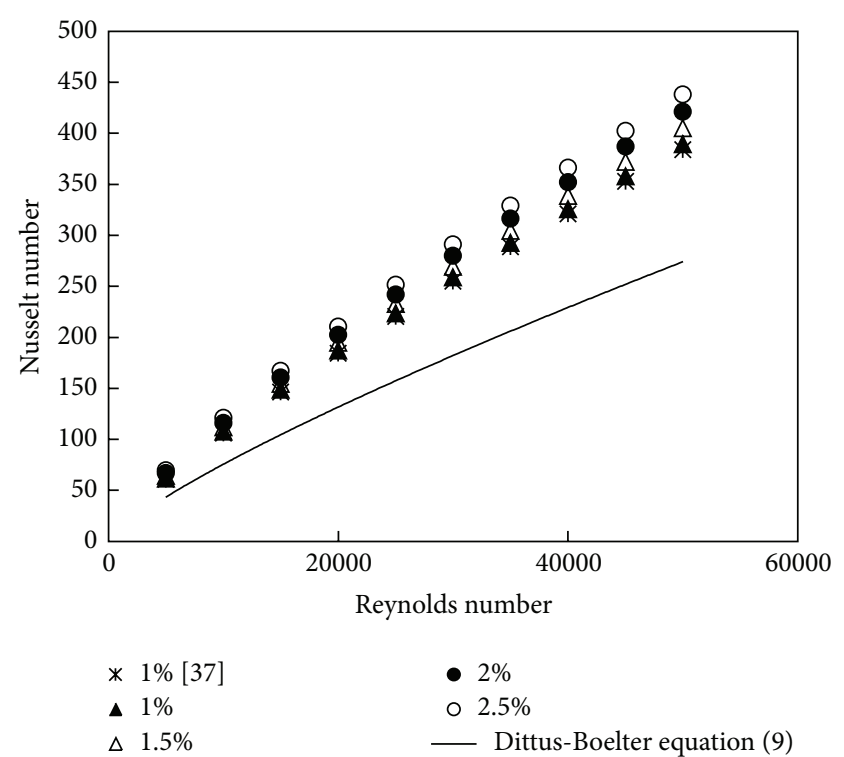

Figure 12: The effect of volume concentration of $\mathrm{SiO}_{2}$-Water on Nusselt number at different Reynolds number.

Nusselt number with Reynolds number at (1-2.5\%) volume concentrations of nanofluid at $25^{\circ} \mathrm{C}$ base temperature. Results showed that the nanofluid has the highest Nusselt number with the highest volume concentration $2.5 \%$ at all Reynolds numbers. The reason of increasing of Nusselt number with the increasing of concentration of volume of nanofluid is the increasing of fluid thermal conductivity. The Nusselt number of $\mathrm{SiO}_{2}$ is the highest value followed by $\mathrm{Al}_{2} \mathrm{O}_{3}$ and $\mathrm{TiO}_{2}$ and the cause may be related to the fact that $\mathrm{SiO}_{2}$ nanofluid has the lowest thermal conductivity than other nanofluids and the highest average velocity among the fluids due to lowest density compared with the others. The fluid velocity plays an important role on the heat transfer in case of forced convection and it represents the main reason to give high heat transfer coefficient [49]. The irregular and random movements of particles increase the energy exchange rates in the fluid with penalty on the wall shear stress and consequently enhance the thermal dispersion of the flow. The CFD analysis of Nusselt number for pure water inside flat tube was compared with Dittus-Boelter equation (9) for water inside circular tube was shown as black solid line. It seems that the values of Nusselt number at flat tube are higher than circular tube referring to enhance heat transfer. The CFD analysis of friction factor and Nusselt number for $\mathrm{Al}_{2} \mathrm{O}_{3}, \mathrm{TiO}_{2}$, and $\mathrm{SiO}_{2}$ was compared with experimental data of Sunder and Sharma [8], Duangthongsuk and Wongwises [17], and Mohammed et al. [49], respectively, as shown in Figure 13. It shows good agreement among CFD analysis and experimental data. Figure 14 illustrated velocity and temperature profiles at different Reynolds number. It seems that the maximum and minimum velocity is 0.135 and $0.958 \mathrm{~m} / \mathrm{s}$ at Reynolds numbers 5000 and 50000, respectively. Furthermore the minimum temperature is 43 and $54^{\circ} \mathrm{C}$ at Reynolds number is 5000 and 50000 respectively. The reason may be related to 

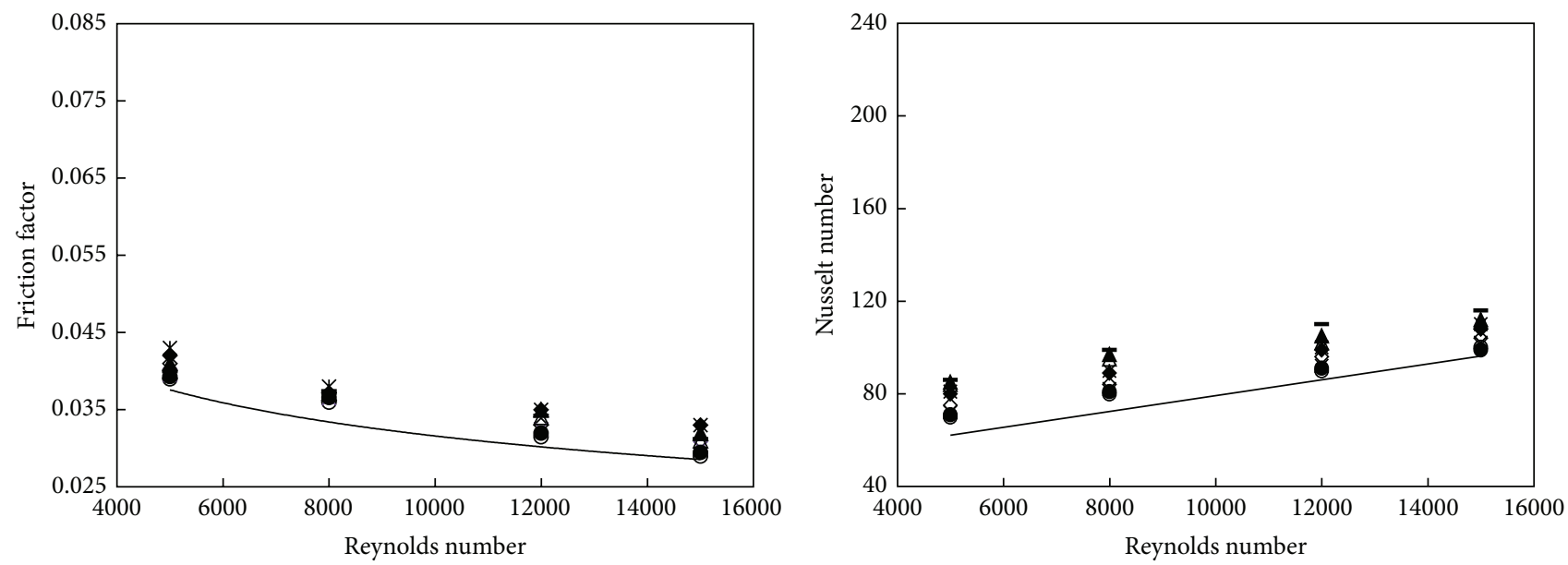
$\diamond 0.1 \% \mathrm{Al}_{2} \mathrm{O}_{3}[8]$
* $1.34 \% \mathrm{Al}_{2} \mathrm{O}_{3}$ [36]
○ $0.99 \% \mathrm{TiO}_{2}$ [36]
$\times 1 \% \mathrm{TiO}_{2}$ [21]
$\triangle 1 \% \mathrm{SiO}_{2}[39]$
- $1 \% \mathrm{SiO}_{2}[49]$
- $1 \% \mathrm{TiO}_{2}$ present study
- $1 \% \mathrm{SiO}_{2}$ present study
- $1 \% \mathrm{Al}_{2} \mathrm{O}_{3}$ present study
- Blasius equation (8)

(a)
$\diamond 0.1 \% \mathrm{Al}_{2} \mathrm{O}_{3}[8]$
* $1.34 \% \mathrm{Al}_{2} \mathrm{O}_{3}$ [36]
○ $0.99 \% \mathrm{TiO}_{2}$ [36]
$\times 1 \% \mathrm{TiO}_{2}[21]$
$\triangle 1 \% \mathrm{SiO}_{2}[39]$

- $1 \% \mathrm{SiO}_{2}[49]$

- $1 \% \mathrm{TiO}_{2}$ present study

- $1 \% \mathrm{SiO}_{2}$ present study

- $1 \% \mathrm{Al}_{2} \mathrm{O}_{3}$ present study

- Dittus-Boelter equation (9)

(b)

FIGURE 13: Validation of CFD analysis with experimental results: (a) friction factor and (b) Nusselt number at different Reynolds number.

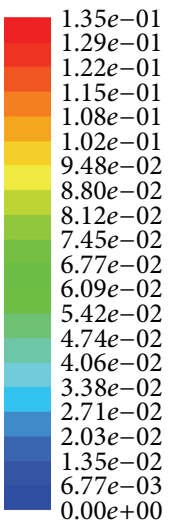

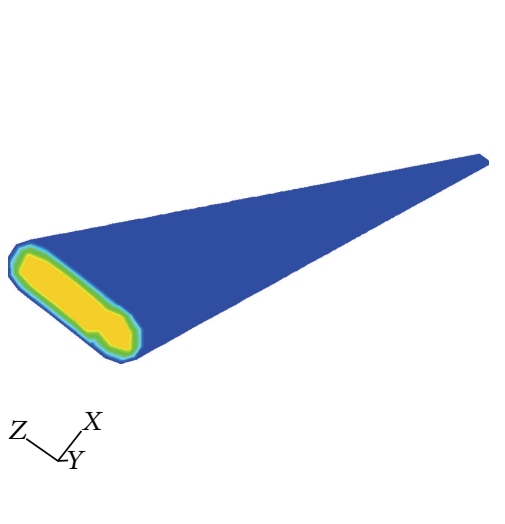

(a) $\mathrm{Re}=5000$

$9.58 e-01$

$9.10 e-01$

$8.62 e-01$

$8.14 e-01$

$7.66 e-01$

$7.18 e-01$

$6.70 e-01$

$6.23 e-01$

$6.23 e-01$
$5.75 e-01$

$5.27 e-01$

$4.79 e-01$

$4.31 e-0$

$3.83 e-01$

$3.35 e-01$

$2.87 e-01$

$2.39 e-01$

$1.92 e-01$

$1.44 e-01$

$9.58 e-02$

$4.79 e-02$

$0.00 e+00$

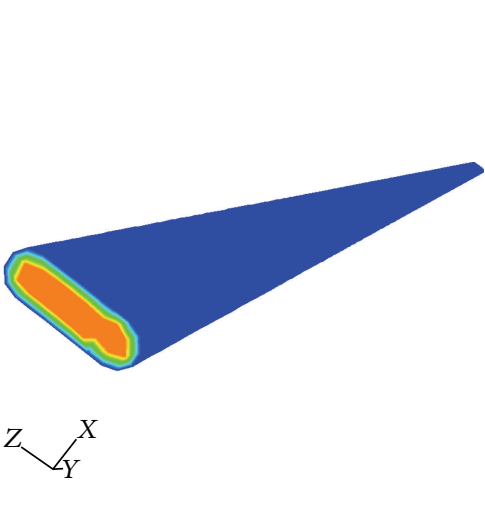

(c) $\mathrm{Re}=50000$

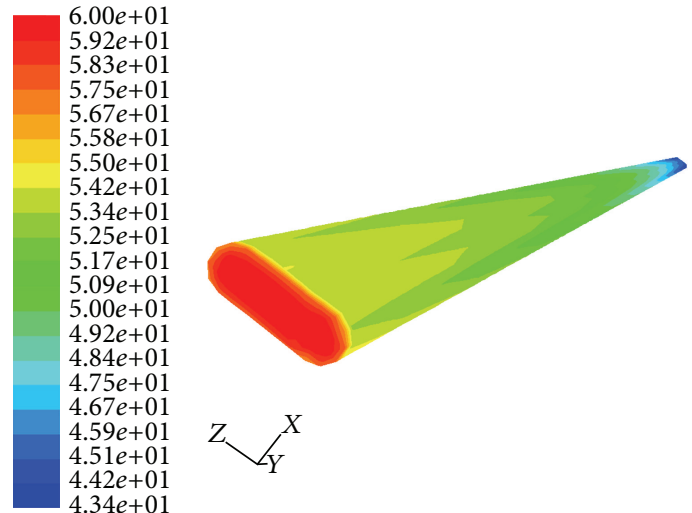

(b) $\mathrm{Re}=5000$
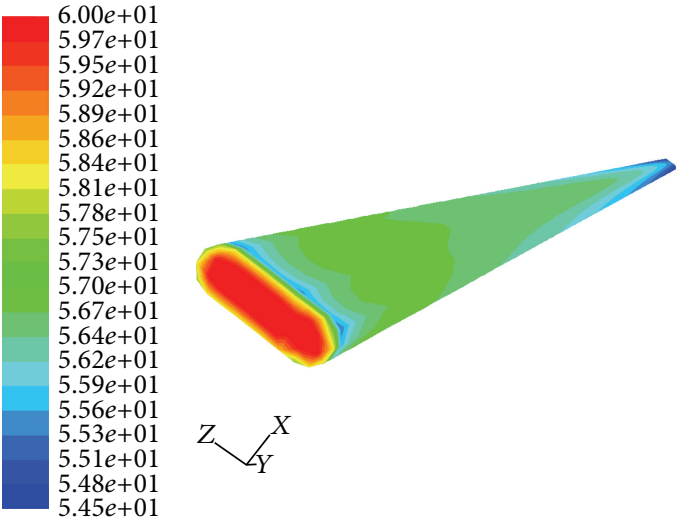

Figure 14: : Contour of velocity and temperature: $(a, c)$ velocity profile, $(b, d)$ temperature distribution. 


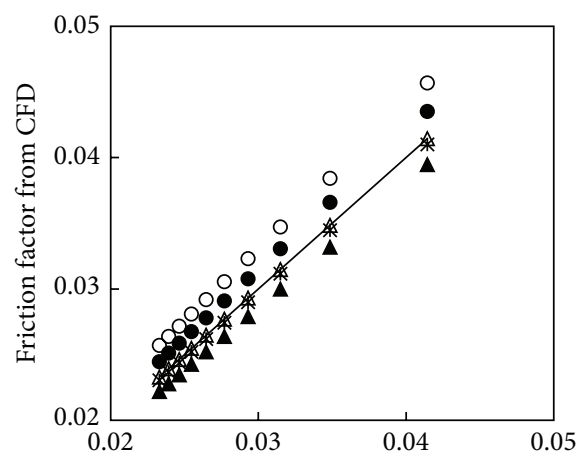

Friction factor from Blasius equation (8)

* $1 \%[17]$

$\Delta 0.01$

$\triangle 0.015$

(a) $\mathrm{TiO}_{2}-\mathrm{W}$

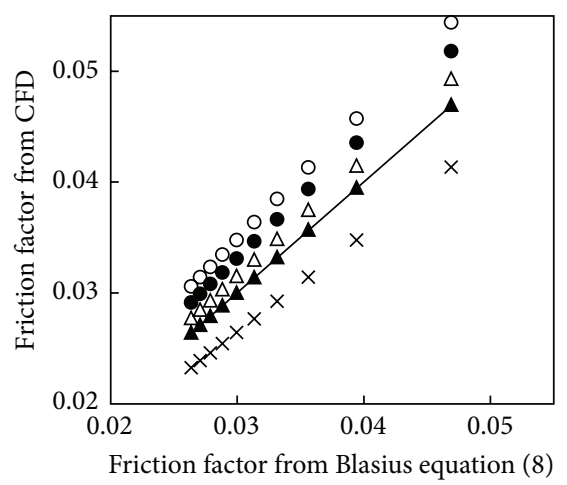

$\times 0.5 \%[8]$

$\Delta 0.01$

0.02

$\triangle 0.015$

○ 0.025

(b) $\mathrm{Al}_{2} \mathrm{O}_{3}-\mathrm{W}$

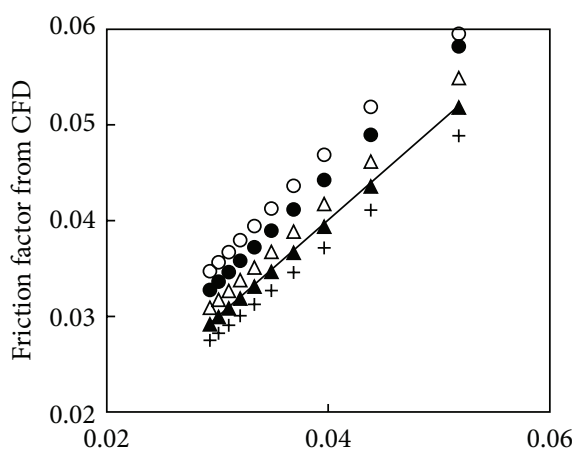

Friction factor from Blasius equation (8)
$+1 \%[37]$
$\Delta 0.01$
0.02
$\triangle 0.015$
0.025

(c) $\mathrm{SiO}_{2}-\mathrm{W}$

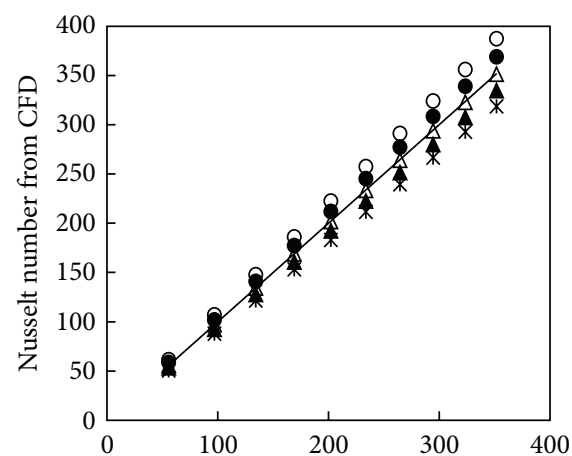

Nusselt number from Dittus-Boelter equation (9)
* $1 \%[17$
$\Delta 0.01$
$\triangle 0.015$

- 0.02

0.025

(d) $\mathrm{TiO}_{2}-\mathrm{W}$

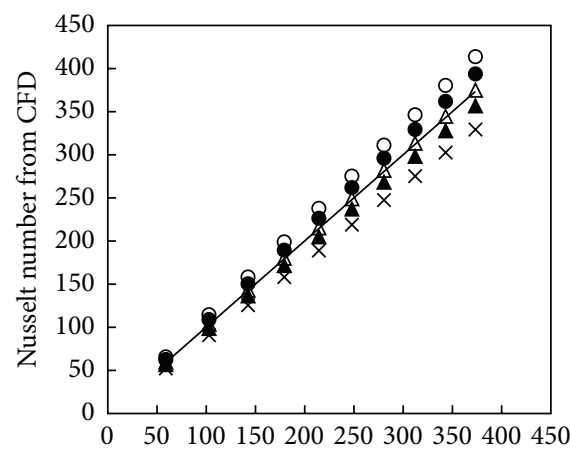

Nusselt number from Dittus-Boelter equation (9)

$\times 0.5 \%[8]$

$\Delta 0.01$

$\triangle 0.015$

(e) $\mathrm{Al}_{2} \mathrm{O}_{3}-\mathrm{W}$

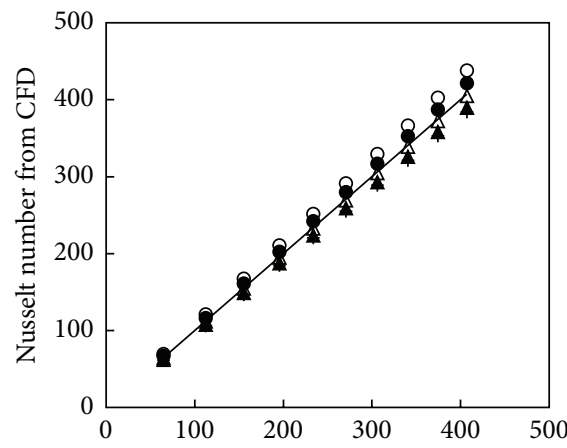

Nusselt number from Dittus-Boelter equation (9)

$+1 \%[37]$

$\Delta 0.01$

$\triangle 0.015$
- 0.02

○ 0.025
- Curve fitting , 
TABLE 2: Constants of friction equation (11).

\begin{tabular}{lccc}
\hline Nanofluid & $a 1$ & $b 1$ & $c 1$ \\
\hline $\mathrm{TiO}_{2}-\mathrm{W}$ & 0.3 & -0.1127 & 0.00100 \\
$\mathrm{Al}_{2} \mathrm{O}_{3}-\mathrm{W}$ & 0.3 & -0.111 & 0.00120 \\
$\mathrm{SiO}_{2}-\mathrm{W}$ & 0.3 & -0.106 & 0.00125 \\
\hline
\end{tabular}

TABle 3: Constants of Nusselt number equation (12).

\begin{tabular}{lccc}
\hline Nanofluid & $a 2$ & $b 2$ & $c 2$ \\
\hline $\mathrm{TiO}_{2}$-W & 0.02 & 0.78 & 0.54 \\
$\mathrm{Al}_{2} \mathrm{O}_{3}$-W & 0.02 & 0.788 & 0.45 \\
$\mathrm{SiO}_{2}$-W & 0.02 & 0.8 & 0.4 \\
\hline
\end{tabular}

the low Reynolds number that is given more time to make deference temperature between input and output of tube. The regression equations among input and output parameters have been analyzed by using Minitab 16 software. The input parameters represented that Reynolds number as a velocity inlet and Prandtl number as a concentration of nanofluid; on the other hand, the output parameters represented friction factor and Nusselt number. Figure 15 showed friction factor and Nusselt number from CFD analysis against (8) and (9) data to correlate among parameters.

These equations are concluded under $5000<\operatorname{Re}<50000$ and $6.8<\operatorname{Pr}<11.97$; the regression equation of friction factor has been expected as

$$
\mathrm{f}=a 1 \times \operatorname{Re}^{b 1} \times \operatorname{Pr}^{c 1} .
$$

Elsewhere, the regression equation of Nusselt number has been found as:

$$
\mathrm{Nu}=a 2 \times \operatorname{Re}^{b 2} \times \operatorname{Pr}^{c 2}
$$

\section{Conclusions}

In the present study, thermal properties of three types of nanoparticles were suspended in water measured experimentally in thermal laboratory. Thermal conductivity and viscosity were measured experimentally between $1 \%$ and $2.5 \%$ volume concentrations at $25^{\circ} \mathrm{C}$. Results of thermal conductivity showed that the increase in volume concentrations and temperatures is due to the increase in thermal conductivity of nanofluids with maximum deviation (19\%) for nanoparticles dispersed in water. The study showed that $\mathrm{Al}_{2} \mathrm{O}_{3}$ nanofluid has the highest values of thermal conductivity followed by $\mathrm{TiO}_{2}$ and $\mathrm{SiO}_{2}$ suspended in water. The data measure also showed that the viscosity of nanofluids significantly increases with increasing particle volume concentration with maximum deviation (6\%) as compared with water. The results showed that $\mathrm{Al}_{2} \mathrm{O}_{3}$ nanofluid has the highest values of viscosity followed by $\mathrm{SiO}_{2}$ and $\mathrm{TiO}_{2}$; finally pure water had the lowest viscosity. The proposed correlations for predicting the thermal conductivity and viscosity of nanofluids showed good agreement with the data measured and the experimental results of $[32,33]$. Forced convection heat transfer under turbulent flow by numerical simulation with uniform heat flux boundary condition around flat tube was studied. The heat transfer enhancement resulting from various parameters such as nanoparticle concentration of volume and Reynolds number were reported. The finite volume methods was used to solve the governing equations with certain assumptions and appropriate boundary conditions. The Nusselt number and friction factor were obtained through the numerical simulation. The study concluded that the enhancement of friction factor and Nusselt number is $-4 \%$ and $6 \%$ for enhanced tube more than that of the circular tube at all Reynolds numbers. The $(2.5 \%)$ volume concentration of nanofluid has the highest friction factor values, followed by $2,1.5$, and $1 \%$. The CFD analysis of pure water friction factor at flat tube has lower values than that of circular tube which estimated from Blasius equation. The Nusselt number of $\mathrm{SiO}_{2}$ is the highest value followed were by $\mathrm{Al}_{2} \mathrm{O}_{3}$ and $\mathrm{TiO}_{2}$. There is a good agreement among the CFD analysis of friction factor and Nusselt number of nanofluid with experimental data of Sunder and Sharma [8], Duangthongsuk and Wongwises [17], and Mohammed et al. [49] with deviation being not more than $2 \%$. The regression equations were found under $5000<\mathrm{Re}<$ 50000 and $6.8<\operatorname{Pr}<11.97$, for friction factor and Nusselt number have been concluded as in (11) and (12), respectively, where the constants of friction equation (11) Nusselt number equation (12) were tabulated as shown in Tables 2 and 3.

\section{Acknowledgment}

The financial support to the authors by University Malaysia Pahang is gratefully acknowledged.

\section{References}

[1] S. K. Das, S. U. S. Choi, and W. Yu, Pradeep, Nanofluids Science and Technology, John Wiley \& Sons, 2007.

[2] S. Sen Gupta, V. Manoj Siva, S. Krishnan et al., "Thermal conductivity enhancement of nanofluids containing graphene nanosheets," Journal of Applied Physics, vol. 110, no. 8, Article ID 084302, 2011.

[3] J. R. V. Peñas, J. M. Ortiz De Zárate, and M. Khayet, "Measurement of the thermal conductivity of nanofluids by the multicurrent hot-wire method," Journal of Applied Physics, vol. 104, no. 4, Article ID 044314, 2008.

[4] H. Xie, W. Yu, Y. Li, and L. Chen, "Discussion on the thermal conductivity enhancement of nanofluids," Nanoscale Research Letters, vol. 6, no. 1, article 124, 2011.

[5] P. K. Namburu, D. P. Kulkarni, A. Dandekar, and D. K. Das, "Experimental investigation of viscosity and specific heat of silicon dioxide nanofluids," Micro and Nano Letters, vol. 2, no. 3, pp. 67-71, 2007.

[6] M. Bahiraei, S. M. Hosseinalipour, K. Zabihi, and E. Taheran, "Using neural network for determination of viscosity in water- $\mathrm{TiO}_{2}$ nanofluid," Advances in Mechanical Engineering, vol. 2012, Article ID 742680, 10 pages, 2012.

[7] S. Bobbo, L. Fedele, A. Benetti et al., "Viscosity of water based SWCNH and $\mathrm{TiO}_{2}$ nanofluids," Experimental Thermal and Fluid Science, vol. 36, pp. 65-71, 2012.

[8] L. S. Sundar and K. V. Sharma, "Turbulent heat transfer and friction factor of $\mathrm{Al}_{2} \mathrm{O}_{3}$ Nanofluid in circular tube with twisted tape 
inserts," International Journal of Heat and Mass Transfer, vol. 53, no. 7-8, pp. 1409-1416, 2010.

[9] A. Durmuş and M. Esen, "Investigation of heat transfer and pressure drop in a concentric heat exchanger with snail entrance," Applied Thermal Engineering, vol. 22, no. 3, pp. 321$332,2002$.

[10] A. E. Bergles, "Heat transfer enhancement-the encouragement and accommodation of high heat fluxes," Transaction ASME, Journal Heat Transfer, vol. 119, no. 1, pp. 8-19, 1997.

[11] C. Yildiz, Y. Biçer, and D. Pehlivan, "Effect of twisted strips on heat transfer and pressure drop in heat exchangers," Energy Conversion and Management, vol. 39, no. 3-4, pp. 331-336, 1998.

[12] R. M. Manglik and A. E. Bergles, "Heat transfer and pressure drop correlations for twisted-tape inserts in isothermal tubes: part II-transition and turbulent flows," Transaction ASME, Journal Heat Transfer, vol. 115, no. 4, pp. 890-896, 1993.

[13] P. K. Sarma, T. Subramanyam, P. S. Kishore, V. D. Rao, and S. Kakac, "Laminar convective heat transfer with twisted tape inserts in a tube," International Journal of Thermal Sciences, vol. 42, no. 9, pp. 821-828, 2003.

[14] S. Z. Heris, E. Talaii, and S. H. Noie, "CuO-water nanofluid heat transfer through triangular ducts," Iranian Journal of Chemical Engineering, vol. 9, no. 1, 2012.

[15] P. Naphon, M. Nuchjapo, and J. Kurujareon, “Tube side heat transfer coefficient and friction factor characteristics of horizontal tubes with helical rib," Energy Conversion and Management, vol. 47, no. 18-19, pp. 3031-3044, 2006.

[16] R. M. Moghari, "Two phase mixed convection $\mathrm{Al}_{2} \mathrm{O}_{3}$-water nanofluid flow in an elliptical tube," International Journal of Multiphase Flow, vol. 3, pp. 585-595, 2011.

[17] W. Duangthongsuk and S. Wongwises, "An experimental study on the heat transfer performance and pressure drop of $\mathrm{TiO}_{2}$ water nanofluids flowing under a turbulent flow regime," International Journal of Heat and Mass Transfer, vol. 53, no. 1-3, pp. 334-344, 2010.

[18] O. S. Prajapati, "Effect of $\mathrm{Al}_{2} \mathrm{O}_{3}$-water nanofluids in convective heat transfer," International Journal of NanoScience, vol. 1, pp. $1-4,2012$.

[19] B. G. Kittur, "On the forced convective flow between two corrugated cylinders," Advances in Theoretical and Applied Mechanics, vol. 3, pp. 491-506, 2010.

[20] N. Bozorgan, M. Mafi, and N. Bozorgan, "Performance evaluation of $\mathrm{Al}_{2} \mathrm{O}_{3}$ /water nanofluid as coolant in a double-tube heat exchanger flowing under a turbulent flow regime," Advances in Mechanical Engineering, vol. 2012, Article ID 891382, 8 pages, 2012.

[21] H. Demir, A. S. Dalkilic, N. A. Kürekci, W. Duangthongsuk, and S. Wongwises, "Numerical investigation on the single phase forced convection heat transfer characteristics of $\mathrm{TiO}_{2}$ nanofluids in a double-tube counter flow heat exchanger," International Communications in Heat and Mass Transfer, vol. 38, no. 2, pp. 218-228, 2011.

[22] R. S. Luciu, T. Mateescu, V. Cotorobai, and T. Mare, "Nusselt number and convection heat transfer coefficient for a coaxial heat exchanger using $\mathrm{Al}_{2} \mathrm{O}_{3}$-water ph=5 nanofluid," Bulletin of the Polytechnic Institute of Jassy, Constructions, Architechture Section, vol. LV (LIX), no. 2, p. 71, 2009.

[23] S. Z. Heris, "Convective heat transfer of a Cu/water nanofluid flowing through a circular tube," Experimental Heat Transfer, vol. 22, pp. 217-227, 2009.
[24] S. Lee, S. U.-S. Choi, S. Li, and J. A. Eastman, "Measuring thermal conductivity of fluids containing oxide nanoparticles," Journal of Heat Transfer, vol. 121, no. 2, pp. 280-288, 1999.

[25] S. K. Das, N. Putra, P. Thiesen, and W. Roetzel, “Temperature dependence of thermal conductivity enhancement for nanofluids," Journal of Heat Transfer, vol. 125, no. 4, pp. 567-574, 2003.

[26] X. Wang, X. Xu, and S. U. S. Choi, "Thermal conductivity of nanoparticle-fluid mixture," Journal of Thermophysics and Heat Transfer, vol. 13, no. 4, pp. 474-480, 1999.

[27] D. Wen and Y. Ding, "Effective thermal conductivity of aqueous suspensions of carbon nanotubes (carbon nanotube nanofluids)," Journal of Thermophysics and Heat Transfer, vol. 18, no. 4, pp. 481-485, 2004.

[28] R. L. Hamilton and O. K. Crosser, "Thermal conductivity of heterogeneous two-component systems," Industrial and Engineering Chemistry Fundamentals, vol. 1, no. 3, pp. 187-191, 1962.

[29] L. Fedele, L. Colla, and S. Bobbo, "Viscosity and thermal conductivity measurements of water-based nanofluids containing titanium oxide nanoparticles," International Journal of Refrigeration, vol. 35, pp. 1359-1366, 2012.

[30] R. S. Vajjha and D. K. Das, "Experimental determination of thermal conductivity of three nanofluids and development of new correlations," International Journal of Heat and Mass Transfer, vol. 52, no. 21-22, pp. 4675-4682, 2009.

[31] M. J. Pastoriza-Gallego, L. Lugo, J. L. Legido, and M. M. Piñeiro, "Thermal conductivity and viscosity measurements of ethylene glycol-based $\mathrm{Al}_{2} \mathrm{O}_{3}$ nanofluids," Nanoscale Research Letters, vol. 6, no. 1, p. 111, 2011.

[32] W. Yu, H. Xie, L. Chen, and Y. Li, "Investigation of thermal conductivity and viscosity of ethylene glycol based $\mathrm{ZnO}$ nanofluid," Thermochimica Acta, vol. 491, no. 1-2, pp. 92-96, 2009.

[33] M. P. Beck, Y. Yuan, P. Warrier, and A. S. Teja, "The effect of particle size on the thermal conductivity of alumina nanofluids," Journal of Nanoparticle Research, vol. 11, no. 5, pp. 1129-1136, 2009.

[34] K. V. Sharma, P. K. Sarma, W. H. Azmi, R. Mamat, and K. Kadirgama, "Correlations to predict friction and forced convection heat transfer coefficients of water based nanofluids for turbulent flow in a tube," International Journal of Microscale and Nanoscale Thermal and Fluid Transport Phenomena, vol. 3, pp. 283-308, 2010.

[35] A. Bejan, Convection Heat Transfer, John Wiley \& Sons, 3rd edition, 2004.

[36] B. C. Pak and Y. I. Cho, "Hydrodynamic and heat transfer study of dispersed fluids with submicron metallic oxide particles," Experimental Heat Transfer, vol. 11, no. 2, pp. 151-170, 1998.

[37] H. Masuda, A. Ebata, K. Teramae, and N. Hishinuma, "Alteration of thermal conductivity and viscosity of liquid by dispersing ultra-fine particles (dispersions of c- $\mathrm{Al}_{2} \mathrm{O}_{3}, \mathrm{SiO}_{2}$, and $\mathrm{TiO}_{2}$ ultrafine particles)," Netsu Bussei, vol. 4, pp. 227-233, 1993.

[38] S. Lee, S. U.-S. Choi, S. Li, and J. A. Eastman, "Measuring thermal conductivity of fluids containing oxide nanoparticles," Journal of Heat Transfer, vol. 121, no. 2, pp. 280-288, 1999.

[39] Y. Xuan and Q. Li, "Heat transfer enhancement of nanofluids," International Journal of Heat and Fluid Flow, vol. 21, no. 1, pp. 58-64, 2000.

[40] J. A. Eastman, S. U. S. Choi, S. Li, W. Yu, and L. J. Thompson, "Anomalously increased effective thermal conductivities of ethylene glycol-based nanofluids containing copper nanoparticles," Applied Physics Letters, vol. 78, no. 6, pp. 718-720, 2001. 
[41] S. M. S. Murshed, K. C. Leong, and C. Yang, "Thermal conductivity of nanoparticle suspensions (nanofluids)," in Proceedings of the IEEE Conference on Emerging Technologies-Nanoelectronics, pp. 155-158, January 2006.

[42] Y. J. Hwang, Y. C. Ahn, H. S. Shin et al., "Investigation on characteristics of thermal conductivity enhancement of nanofluids," Current Applied Physics, vol. 6, no. 6, pp. 1068-1071, 2006.

[43] H. Zhu, C. Zhang, Y. Tang, J. Wang, B. Ren, and Y. Yin, "Preparation and thermal conductivity of suspensions of graphite nanoparticles," Carbon, vol. 45, no. 1, pp. 226-228, 2007.

[44] N. R. Karthikeyan, J. Philip, and B. Raj, "Effect of clustering on the thermal conductivity of nanofluids," Materials Chemistry and Physics, vol. 109, no. 1, pp. 50-55, 2008.

[45] X. J. Wang and X. F. Li, "Influence of $\mathrm{pH}$ on nanofluids' viscosity and thermal conductivity," Chinese Physics Letters, vol. 26, no. 5, Article ID 056601, 2009.

[46] B. L. Dehkordi, S. N. Kazi, M. Hamdi, A. Ghadimi, E. Sadeghinezhad, and H. S. C. Metselaar, "Investigation of viscosity and thermal conductivity of alumina nanofluids with addition of SDBS," Heat and Mass Transfer, 2013.

[47] K. R. Priya, K. S. Suganthi, and K. S. Rajan, “Transport properties of ultra-low concentration $\mathrm{CuO}$-water nanofluids containing non-spherical nanoparticles," International Journal of Heat and Mass Transfer, vol. 55, pp. 4734-4743, 2012.

[48] B. Barbés, R. Páramo, E. Blanco et al., "Thermal conductivity and specific heat capacity measurements of $\mathrm{Al}_{2} \mathrm{O}_{3}$ nanofluids," Journal of Thermal Analysis and Calorimetry, vol. 111, pp. 16151625, 2013.

[49] H. A. Mohammed, H. A. Hasan, and M. A. Wahid, "Heat transfer enhancement of nanofluids in a double pipe heat exchanger with louvered strip inserts," International Communications in Heat and Mass Transfer, vol. 40, pp. 36-46, 2013.

[50] FLUENT Incorporated, FLUENT 6. 2 User Manual, 2006.

[51] R. S. Vajjha and D. K. Das, "Experimental determination of thermal conductivity of three nanofluids and development of new correlations," International Journal of Heat and Mass Transfer, vol. 52, no. 21-22, pp. 4675-4682, 2009.

[52] A. M. Hussein, R. A. Bakar, K. Kadirgama, and K. V. Sharma, "Experimental measurements of nanofluids thermal properties," International Journal of Automotive \& Mechanical Engineering, vol. 7, pp. 850-864, 2013.

[53] M. N. Pantzali, A. G. Kanaris, K. D. Antoniadis, A. A. Mouza, and S. V. Paras, "Effect of nanofluids on the performance of a miniature plate heat exchanger with modulated surface," International Journal of Heat and Fluid Flow, vol. 30, no. 4, pp. 691699, 2009. 

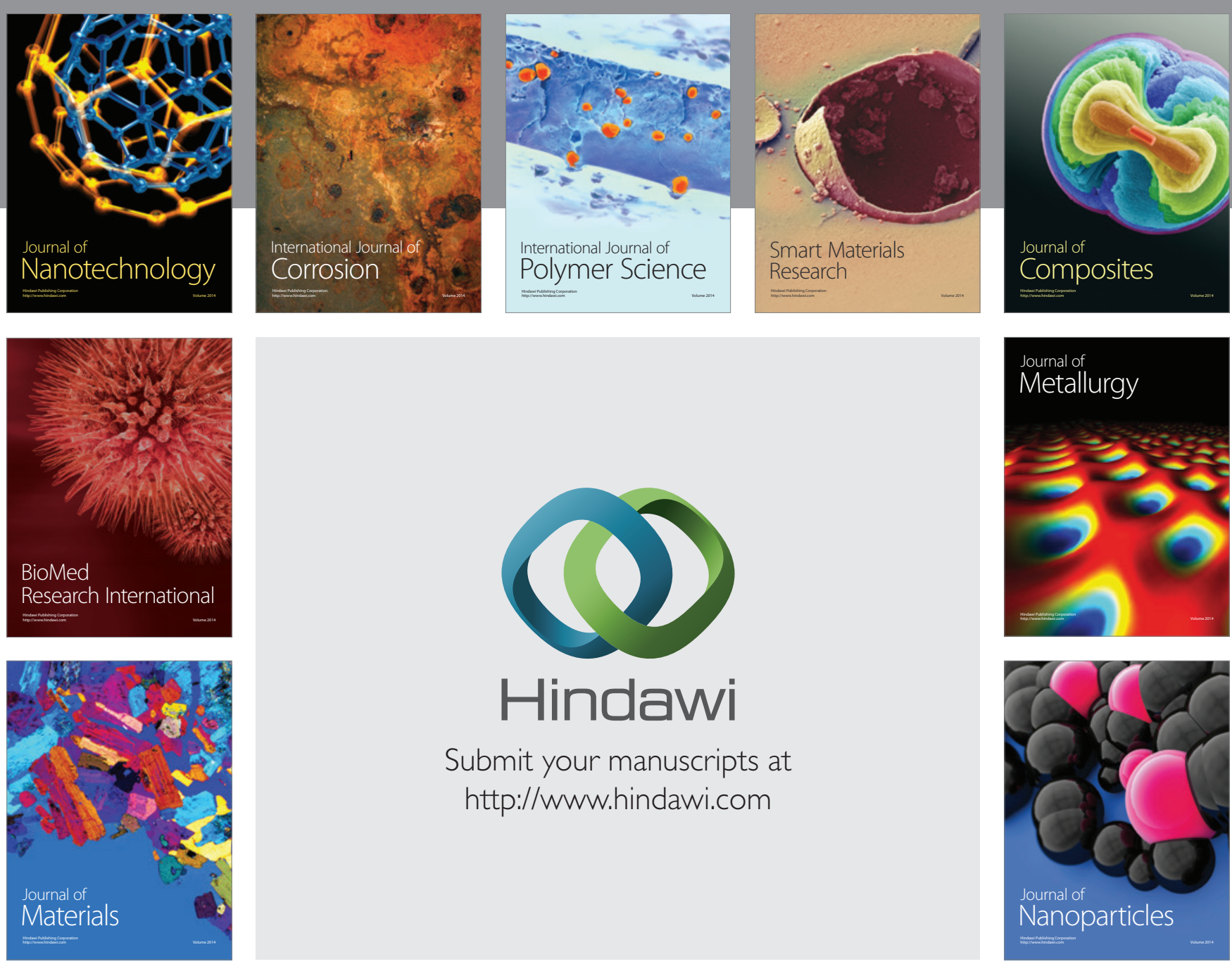

Submit your manuscripts at http://www.hindawi.com
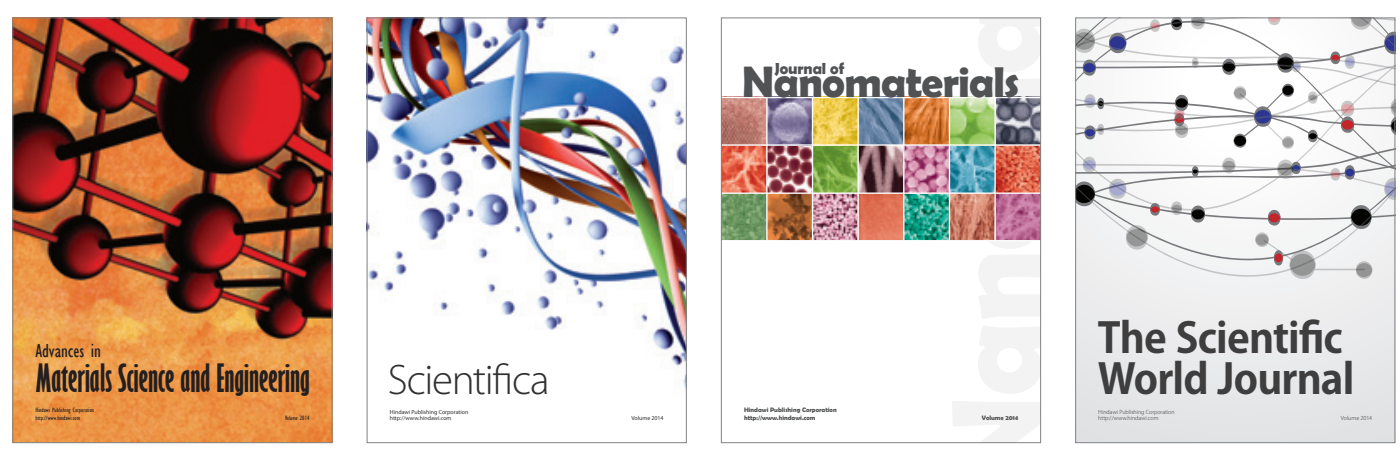

\section{The Scientific World Journal}
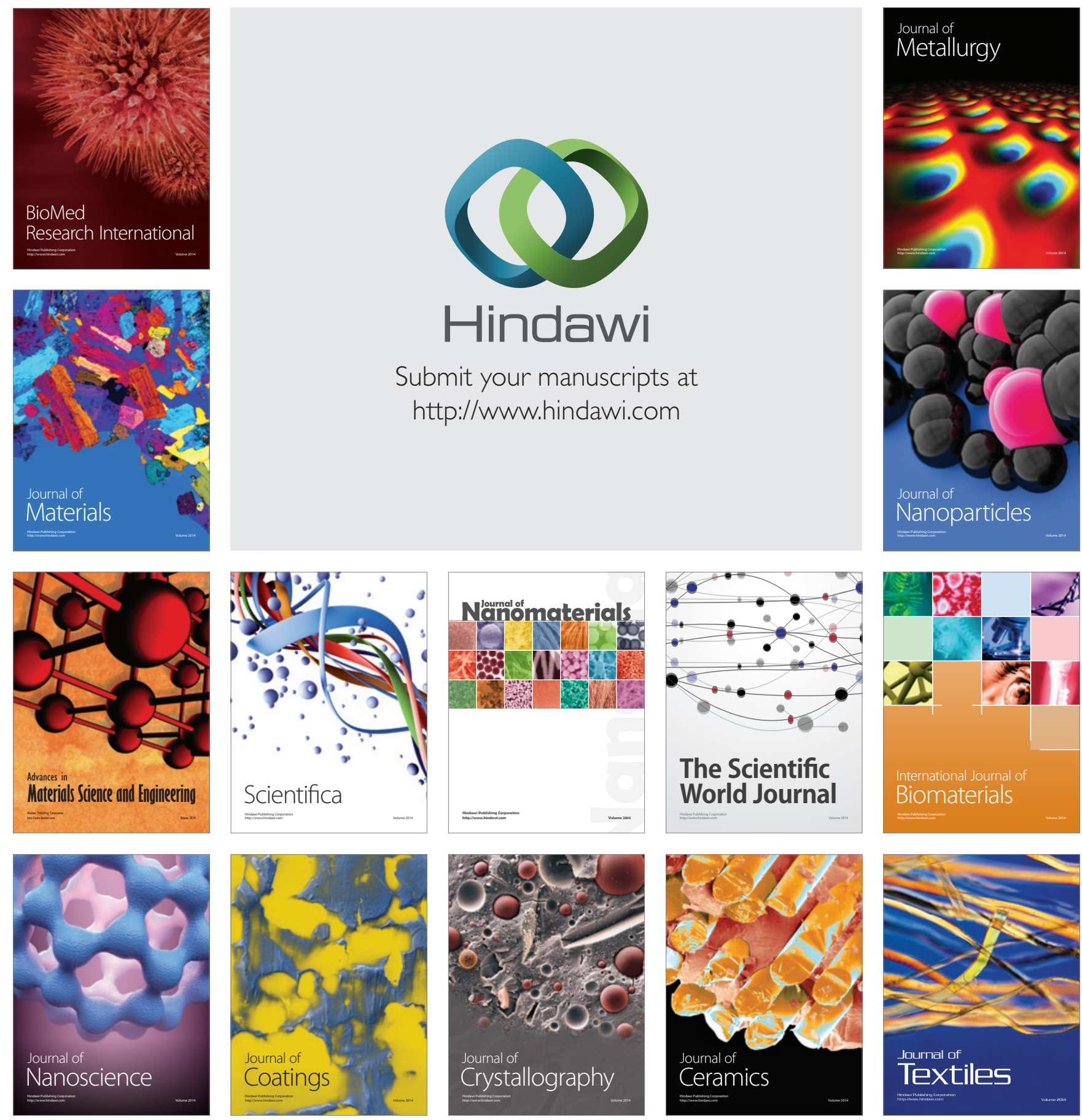